\title{
Multidisciplinary Approach for a Basement Aquifer Location in Tanda Region, Côte d'Ivoire
}

\author{
Adama Coulibaly1 ${ }^{*}$, Omer Zéphir de Lasme², Ta Marc Youan³ , Gbombélé Soro1, Théophile Lasm¹, \\ Nagnin Soro ${ }^{1}$
}

\begin{abstract}
${ }^{1}$ Laboratory of Sciences and Techniques of Water and Environment, Training and Research Unit of Earth, Sciences and Mineral Resources, University Felix Houphouet-Boigny, Abidjan, Côte d'Ivoire

${ }^{2}$ Department of Geosciences, Training and Research Unit, University Péléforo Gon Coulibaly, Korhogo, Côte d'Ivoire ${ }^{3}$ University Research Center of Remote Sensing and Application (CURAT), Training and Research Unit of Earth Sciences and Mineral Resources, University Felix Houphouet-Boigny, Abidjan, Côte d'Ivoire Email: *coulibaly.adama2@univ-fhb.edu.ci,drdelasme@gmail.com, marc.youan@curat-edu.org, gbombele.soro@univ-fhb.edu.ci,soro_nagnin@yahoo.fr
\end{abstract}

How to cite this paper: Coulibaly, A., de Lasme, O.Z., Youan, T.M., Soro, G., Lasm, T. and Soro, N. (2019) Multidisciplinary Approach for a Basement Aquifer Location in Tanda Region, Côte d'Ivoire. Journal of Water Resource and Protection, 11, 1111-1128. https://doi.org/10.4236/jwarp.2019.119065

Received: August 6, 2019

Accepted: September 1, 2019

Published: September 4, 2019

Copyright (C) 2019 by author(s) and Scientific Research Publishing Inc. This work is licensed under the Creative Commons Attribution International License (CC BY 4.0).

http://creativecommons.org/licenses/by/4.0/

\section{Abstract}

The lack of knowledge about fracture systems in Tanda region has led to an approximative establishment of drilling and so a difficult access to groundwater. Thus, a multidisciplinary approach including satellite imagery and electrical resistivity method was conducted with the main objective to locate productive fractures of water in the study area. Indeed, 195-54, 195-55, 196-54, and 196-55 scenes of Landsat $7 \mathrm{ETM}^{+}$satellite images were used. Also, sixty-two (62) vertical electrical soundings (VES) of the Schlumberger configuration and hundred twenty-nine (129) electrical trailing (ET) were performed with a resistivity-meter SYSCAL Pro. Thanks to different treatments applied to satellite images, structural lineaments have been extracted whose main directions are N00-10 (N-S), N90-100 (E-W), N70-80 and N100-110. The interpretation of electrical trailing data made it possible to validate the lineament map by the determination of the fracturing directions. Those are NW-SE, N-S, NE-SW and to some extent E-W. The result of the electrical sounding data showed the presence of three geoelectric layers comprising firstly cuirass and lateritic clays and possibly topsoil, secondly sands and/or clay sandstone and firdly either granites or sandstones or schists. The second geoelectrical layer corresponds to the potential aquifer because of its relatively low electrical resistivity values (13 $\Omega \cdot \mathrm{m}$ to 180 or $240 \Omega \cdot \mathrm{m}$ ). In addition, drillings established at the right of these geological structures provided an average water yield of $4.22 \mathrm{~m}^{3} \cdot \mathrm{h}^{-1}$, sufficient for rural hydraulic. Moreover, these results made it possible to obtain a correlation between drilling productivity and the major directions of fracturing. This indicates that the most productive directions are in order of importance NE-SW, NW-SE, E-W and 
finally N-S. They also correspond to the major fracturing directions of Tanda region. These results are encouraging and contribute to a better implementation of future drilling in this region.

\section{Keywords}

Multidisciplinary, Satellite Images, Resistivity Method, Electrical Soundings, Electrical Trailing, Aquifers, Fractures

\section{Introduction}

Underground water in the basement area is being increasingly exploited to supply drinking water to the population. However, there is a lack of knowledge problem of the fissured environment and consequently of the precise location of aquifers [1]. The latter meets either in alterities, in the cracked horizon, or in deep faults.

In Côte d'Ivoire, despite all the efforts, the rate of drinking water access in 2014 is estimated at $65 \%$ in the countryside and around 70\% in urban areas. The economic capital of Côte d'Ivoire, Abidjan, does not exceed this threshold either [2]. The Tanda region is not an exception to this reality of low coverage of water needs. In addition to the low rainfall that is unfavorable to aquifer recharge, the population growth strongly influences the availability of water, quantitatively and qualitatively. According to the National Institute of Statistics, the population has grown from 228,820 inhabitants in 1998 to 277,263 inhabitants in 2014 [3]. Water needs become important.

The coverage of populations drinking water needs is therefore closely linked to a better knowledge of the discontinuous environments in which drillings that can deliver large flows are located. The objective of this study is to locate the basement aquifers from fracturing study in order for judicious drilling in Tanda region (north-eastern Côte d'Ivoire).

\section{Presentation of the Study Area}

\subsection{Geographical Situation}

Tanda Department is located at north-eastern of Côte d'Ivoire, between longitudes $02^{\circ} 51^{\prime} \mathrm{W}$ and $03^{\circ} 52^{\prime} \mathrm{West}$ and latitudes $07^{\circ} 03^{\prime} \mathrm{N}$ and $08^{\circ} 02^{\prime} \mathrm{N}$ (Figure 1).

It covers an area of approximately $6422 \mathrm{~km}^{2}$ and is limited to the North by the Bondoukou and Sandégué departments, to the South by the Agnibilékro department, to the East by the Republic of Ghana and to the West by the departments of Prikro and Daoukro. It consists of thirteen sub-prefectures, including Kouassi-Datékro, Tankéssé, Transua, Koun-fao, Assuéfry and Tanda.

\subsection{Geological and Hydrogeological Contexts}

\subsubsection{Geological Context}

The geological context of Tanda region is very complex and belongs the Paleoproterozoic field of Côte d'Ivoire. It consists of several types of formations 


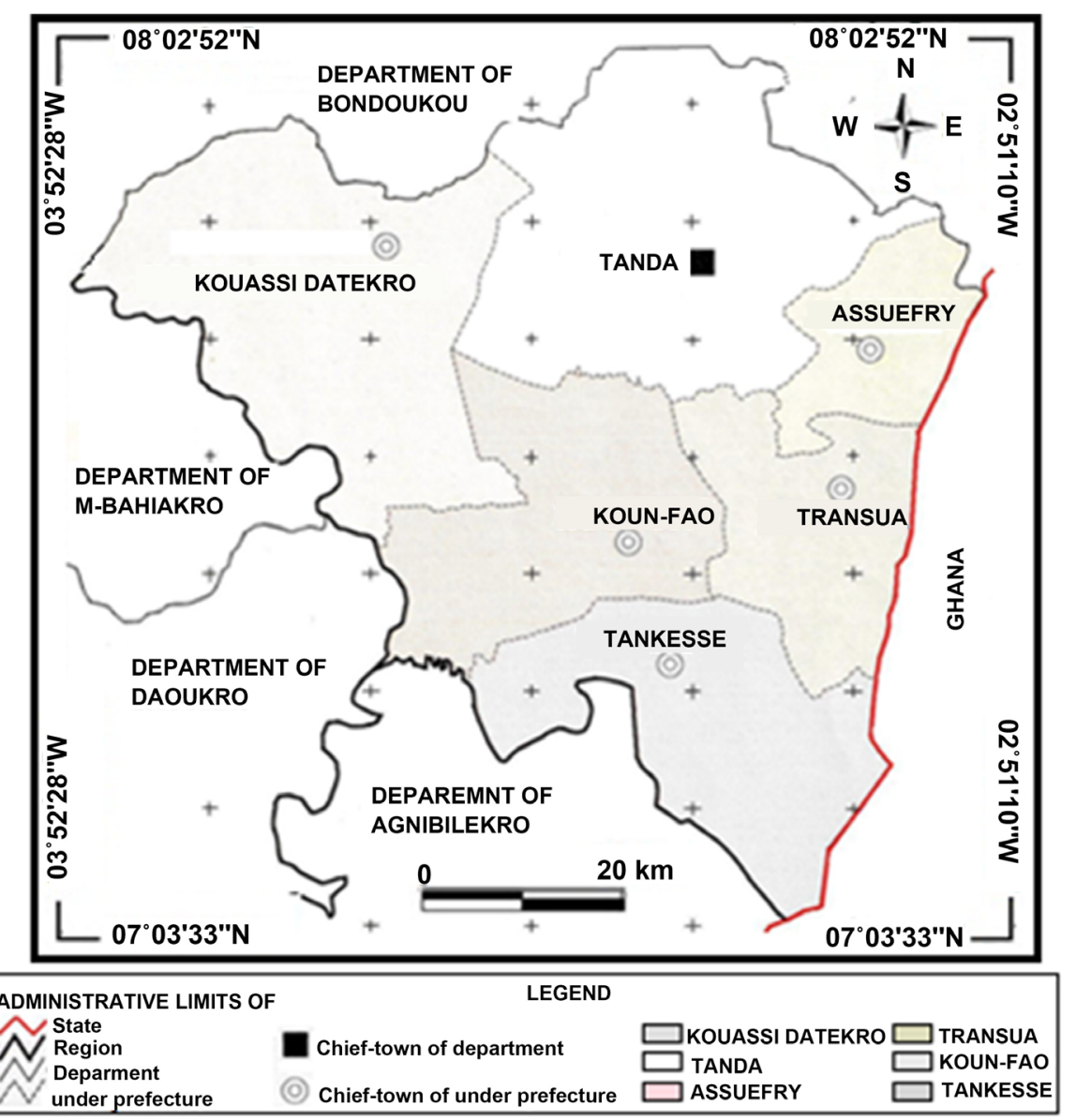

Figure 1. Presentation of the study area.

(intrusive formations, tarkwaïennes and volcano-sedimentary) of varying ages [4] [5] [6] (Figure 2).

These geological sets are fractured and metamorphosed by the different tectono-metamorphic events that have occurred in the region. We also note the presence of the quaternary domain consisting of lateritic cuirasses, vases and fluvial sands.

\subsubsection{Hydrogeological Aspect}

The precise location of fractures and their characterization constitute the essential of groundwater prospecting. The most significant groundwater reserves are contained. These aquifers are developing in the crushed and/or fissured rock and are protected from seasonal fluctuations and various sources of pollution [7] [8]. In tropical climates, these fractures are rarely visible in the ground because of thick layers of weathering which cover them. These layers are variable thickness with an average of $30 \mathrm{~m}$ and can sometimes reach $80 \mathrm{~m}$ on the granites and 100 $\mathrm{m}$ on the schists [7]. Due to the presence of clays, alterites are characterized by relative low permeability but significant storage capacities [9]. This compartment when saturated provides a capacitive function of groundwater storage. The majority of wells in the study area mainly tap these alterites. These aquifers are 


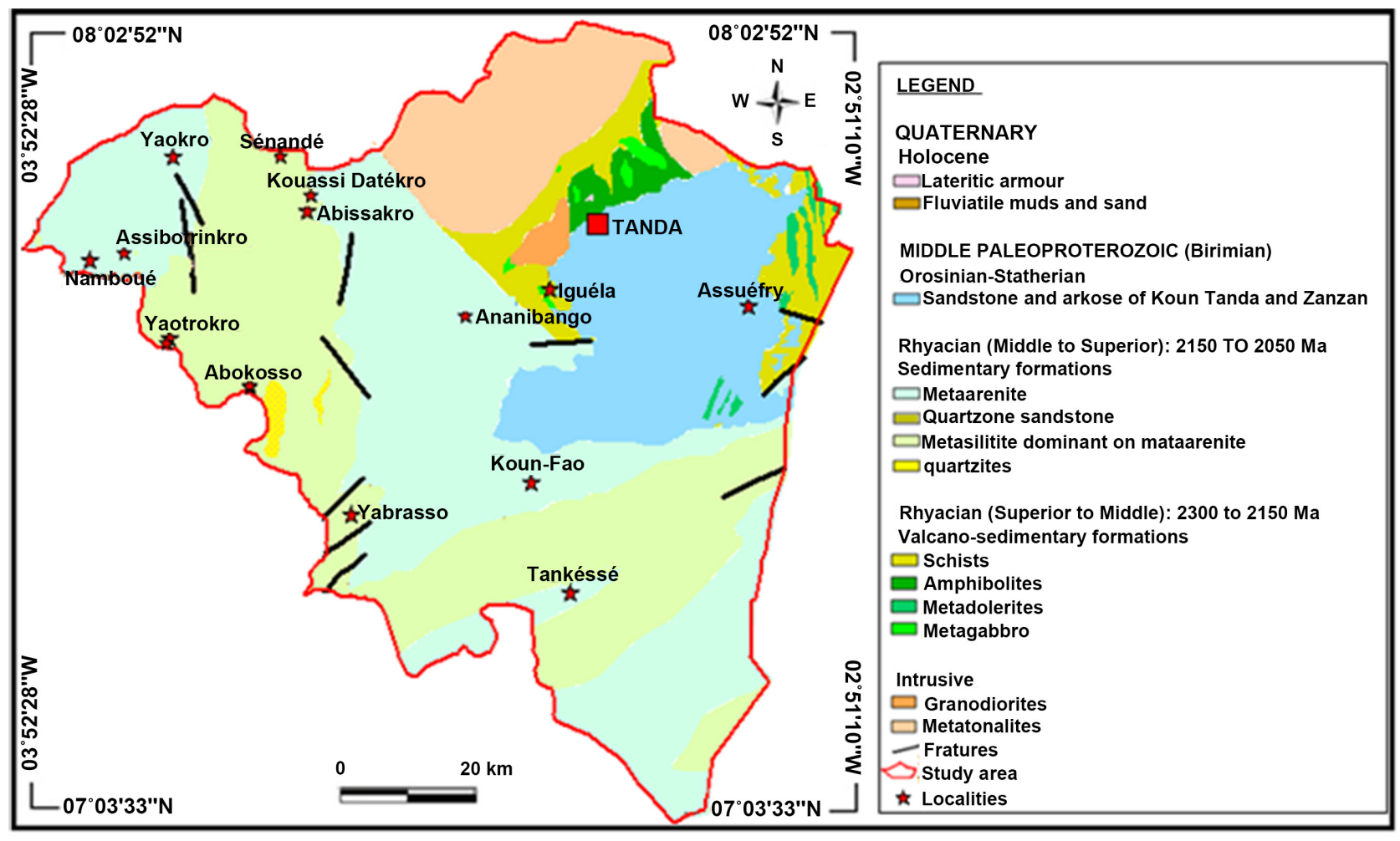

Figure 2. Geological map of study area.

exposed to pollution. Consequently, in addition to water sustainability problem, there are problems related to water potability so that villager hydraulics programs are directed towards deep and more stable groundwater capture.

\section{Materials and Methods}

\subsection{Data and Material}

The main data used come from several villager hydraulics campaigns carried out in Tanda department, whose "BADEA 2 project". This project has been conducted from January to June 2007. These data are essentially the alteration thickness, the lithology and the drilling flows. Also, electrical resistivity data from geophysical prospecting were acquired as part of the project. In total, 142 drillings were used to conduct the study. For the validation of the fracturing map, 89 of them were selected: 39 drillings implanted by geophysics and the 50 others implanted after a geomorphological study.

Geological maps have also been used. These are the square degree maps of Agnibilékrou-Kouamé Dari and Bondoukou [4], established on 1/200,000. They allowed to restore the geological sketch of the study area but also generate a basic fracturing map.

Then Landsat $7 \mathrm{ETM}^{+}$satellite images were used. These are 195-54, 195-55, 196-54, and 196-55 scenes and $\mathrm{ETM}^{+} 1, \mathrm{ETM}^{+} 2, \mathrm{ETM}^{+} 3, \mathrm{ETM}^{+} 4, \mathrm{ETM}^{+} 5, \mathrm{ETM}^{+} 7$ bands, all with square pixels of $30 \mathrm{~m}$ and the $\mathrm{ETM}^{+} 6$ band of the $60 \mathrm{~m}$ pixels. These images were used to make a linear map of the study area. 
Then, the electrical resistivity data were measured using a resistivity meter SYSCAL Pro. A total of 62 vertical electrical surveys (SEV) and 129 electrical trailing (TE) were conducted in the study area (Figure 3 ). These vertical electrical surveys were punctual electrical measurements, based on a variable spacing of electrodes (Schlumberger device) in order to explore deeper and deeper layers. On the other hand, the electrical trailing (TE) were exhaustive electrical measurements, lateral and quasi continuous according to the device "rectangle gradient" in order to locate possible discontinuities.

Finally, all the data were exploited by using several softwares including Envi 3.0, MapInfo 7.5, WinSev 3.3 and Linwin 2.0.

\subsection{Study Methods}

\subsubsection{Method of Processing Satellite Images}

Lineaments mapping in the study area was made by different treatments applied to the Landsat $7 \mathrm{ETM}^{+}$(Enhanced Thematic Mapper) raw image.

Before identifying and extracting the lineaments, satellite images were pretreated in order to eliminate the background noise and correct the geometric distortions. Then, to enhance these images, their processing was performed through principal component analysis (PCA), color compositions, and directional spatial filtering. The PCA consisted of two primary selective component analyzes (CSPA), first with bands 1, 2 and 3 and then with bands 5, 6 and 7 of $\mathrm{ETM}^{+}$. Each of them yielded three components, respectively $\mathrm{ACP} 1_{123}, \mathrm{ACP} 2_{123}$ and $\mathrm{ACP} 3_{123}$ and $\mathrm{ACP} 1_{567}, \mathrm{ACP} 2_{567}$ and $\mathrm{ACP} 3_{567}$. The treatment in red-green-blue

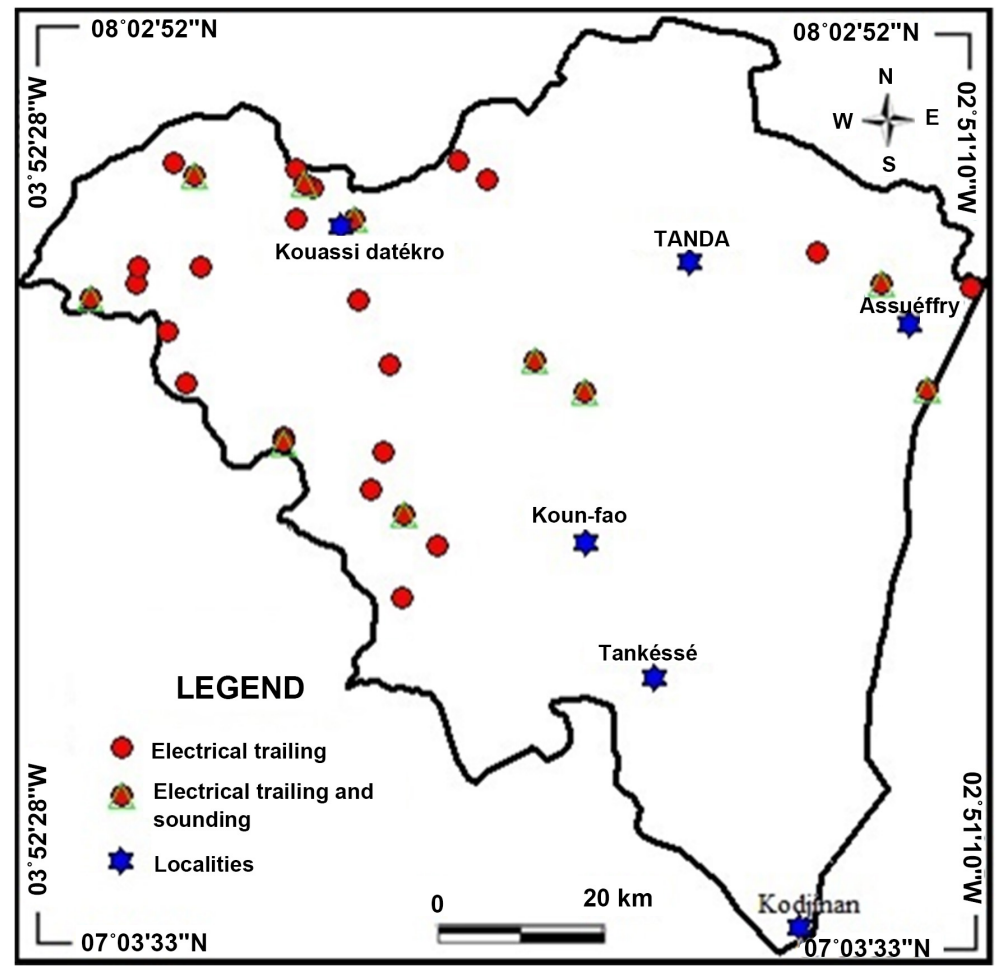

Figure 3. Positioning map of TE and SE performed in the study area. 
color compositions of $\mathrm{ETM}^{+}$bands 1 to 7 improves the quality of the resulting image. This highlights the targeted geological structures. Concerning the directional spatial filtering, only Sobel filters in four directions were applied to the corrected and enhanced images. In practice, Sobel filters $7 \times 7$ in directions N-S; E-O, NE-SO and NO-SE were used.

\subsubsection{Interpretation of Electrical Resistivity Data}

The interpretation of electrical resistivity data starts with the construction of electrical profiles on which conductive anomalies are detected. At the right of these conductive anomalies, electrical soundings are executed and then soundings curves are established.

\section{a) Electrical Trailing}

The electric trainers were implemented according to the "gradient rectangle" device. The resulting electrical profiles are made using the Microsoft Office Excel spreadsheet. On these graphs, two types of anomalies can be distinguished: conductive anomalies corresponding to areas of low resistivities and resistive anomalies which are zones of strong resistivities. These anomalies are characterized in the field by a significant lateral variation of electrical resistivities. Thus, from the parallel profiles, several discontinuities are highlighted and traced taking into account the forms of anomaly. The direction of each discontinuity is then determined from the orientation of the electrical profiles on which these discontinuities have been identified.

\section{b) Electrical Soundings}

The advantage of this technique is to locate anomalies in-depth. In basement zone, the conductive anomaly corresponds to discontinuities, which constitute the main reservoirs of groundwater.

The most efficient method of interpreting electrical sounding data is the use of inversion algorithms. These latter, from a basement model (drill cut) and knowing the potential equation to the surface for a given electrode arrangement, will restore an approximate model. This model fits as closely as possible to the curve of measurements. The inversion calculation was done with the WinSev3.3 software. This interpretation results in the determination of the thickness $\mathrm{h} 1$ and the true resistivity $\rho 1$ of the first layer, the thickness h2 and the true resistivity $\rho 2$ of the second layer and finally the true resistivity $\rho 3$ of the third layer. The method principle consists of looking for the best superimposition between experimental (field data) and theoretical (model) curves with three, four or five layers (theoretical schemas of Schlumberger).

The coupling of these two geophysical techniques (TE and SE) results gives precise indications (location, orientation and depth) on the fractures. It therefore makes it possible to implement boreholes that can provide more or less significant flow rates (Figure 4).

\subsubsection{Validation}

The validation of the lineaments map begins with the removal of all linear 


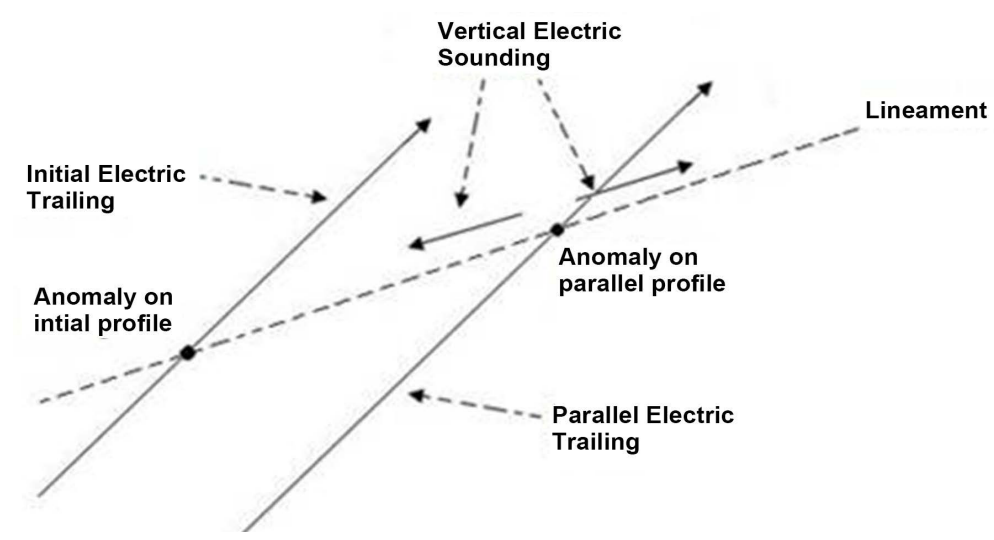

Figure 4. Methodology for implementing TE and SE.

structures of anthropogenic origin (energy transport wires, rectilinear borders of large industrial plantations, tracks, paved roads, landing strips, etc.).

Lineaments identified from the Landsat 7 ETM+ images were subjected to a frequency analysis to highlight the main directions. In order to validate them, their main directions were first compared with those of the geological accidents recorded on the geological map [4] [5]. Then, they were compared to the principal directions of the basement discontinuities identified from electrical resistivity profiles. Finally, all the drill holes established following the geophysical prospection as well as some boreholes with significant flows of the study area are positioned on the linear map. This aims to highlight some major fractures. Indeed, according to [10], the most productive boreholes are located on major accidents and can therefore be an essential tool for the validation of lineaments.

This validation phase leads to the development of the map of major fractures in the study area. This is representative of the geological structures of the study area and constitutes useful support for a better location of the aquifers in the basement area.

Following the development of this fracturing map, we studied drilling productivity according to the fracturing directions. This study consisted of analyzing the different flow rates of geophysically-implanted boreholes according to the orientation of the fractures on which these holes are implanted.

\section{Results and Discussion}

\subsection{Fracturing Card}

Figure 5 shows lineaments map of the study area. This one has a high density of lineaments with variable sizes and directions from one part of the study area to another. Fracture lengths range from a few hundred meters $(0.5 \mathrm{~km})$ to several kilometers $(51 \mathrm{~km})$.

\subsubsection{Analysis of Lineaments}

The lineaments map has a network comprising 1.829 lineaments. Histograms of the principal directions (in lineaments number and cumulated length) and the corresponding directional rosettes are illustrated in Figure 6. 


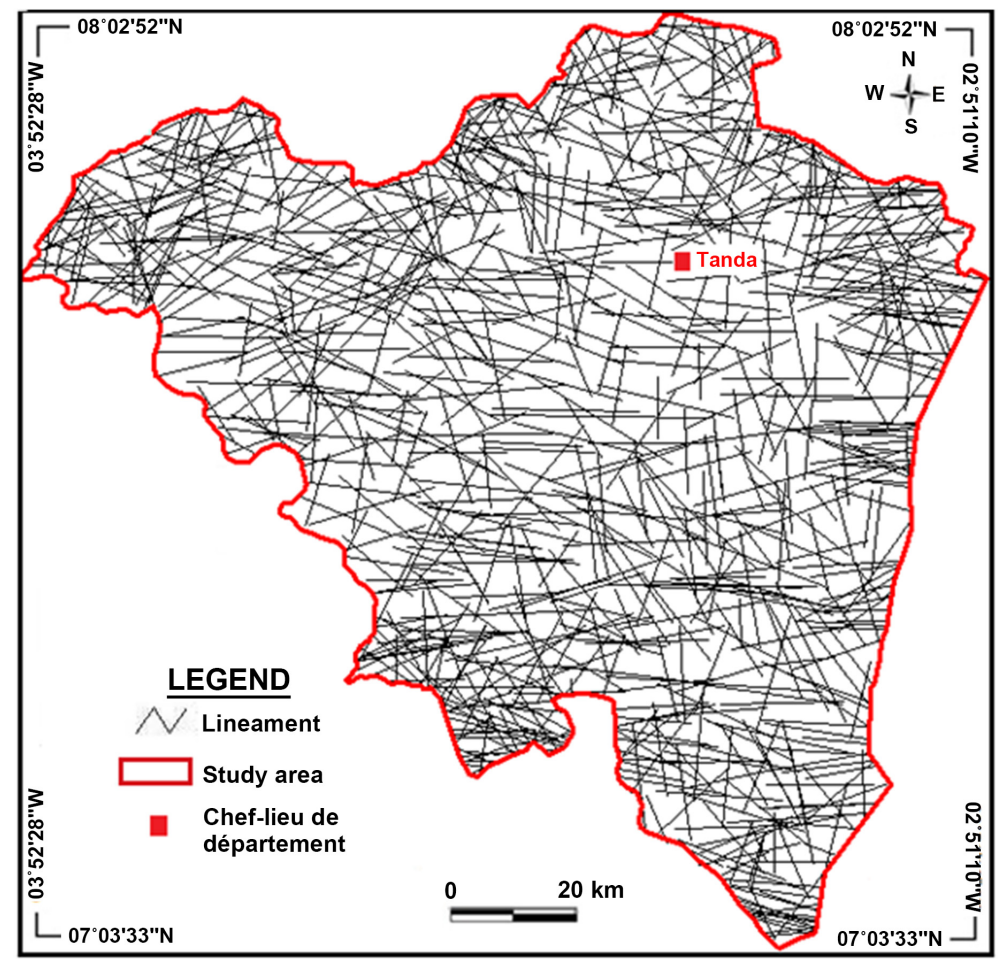

Figure 5. Linear map of the Tanda region.

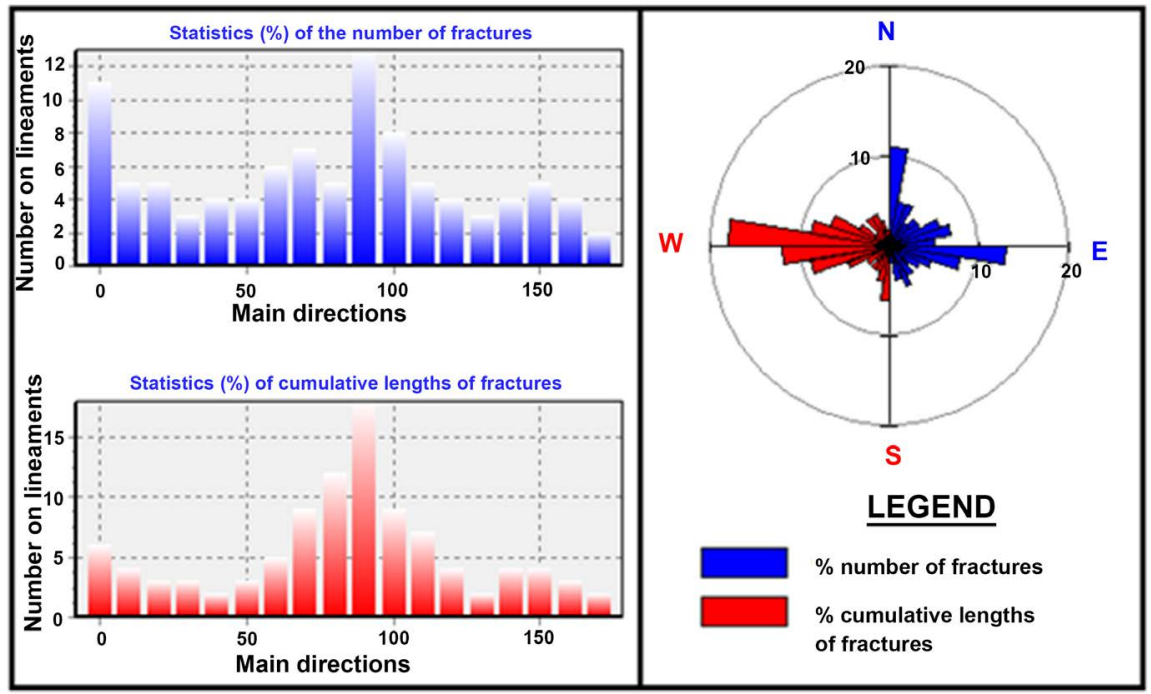

Figure 6. Graphical representation of statistical parameters of lineaments from satellite images.

The analysis of these rosettes indicates that the fracture families N00-10 (N-S) and N90-100 (E-W) constitute the main families of fracturing with respectively $12 \%$ and $14 \%$ frequency. Two other families have frequencies close to $8 \%$. These are the N70-80 and N100-110 families. The last families of fractures have frequencies lower than 6\%; they are minor families. The fracturing of Tanda region is therefore generally heterogeneous.

As regards the cumulative lengths, the observation is the same as above. In- 
deed, N80-90 and N90-100 families appear to be the most dominant. Similarly, those of N70-80 and N100-110 have frequencies close to $8 \%$. The rest of the families have a frequency lower than $6 \%$. Thus, we can notice that the most dominant families of fractures are also the longest.

\subsubsection{Validating the Linear Card}

The fracturing map based on the geological map reveals forty-two (42) fractures (Figure 7).

On the directional rosette of these fractures (Figure 8), three main families of fractures are released: N50-60 (12\%), N0-10 and N70-80 (10\%). To these are added the families N20-30, N60-70 and N170-180 (9\%) which are secondary fractures.

For the cumulative lengths, the highest frequency percentages correspond to the N50-60 (15\%), N70-80 (13\%) and N60-70 (11\%) families. In addition, two classes of fractures $\mathrm{N} 20-30(9 \%)$ and N170-180 (8\%) have intermediate frequencies.

The distribution of these fractures confirms two principal directions of lineaments namely N-S and NE-SW directions. These two directions have respectively proportions of $10 \%$ and $12 \%$.

Figure 9 relates to the map of fractures identified from the electrical profiles.

Seventy-one (71) fractures are highlighted. Some of these are materialized on Figure 10.

Fractures distribution in the circular diagram (Figure 11) shows that the major classes in fractures numbers are N110-120 (12\%), N120-130 (11\%), N150-160

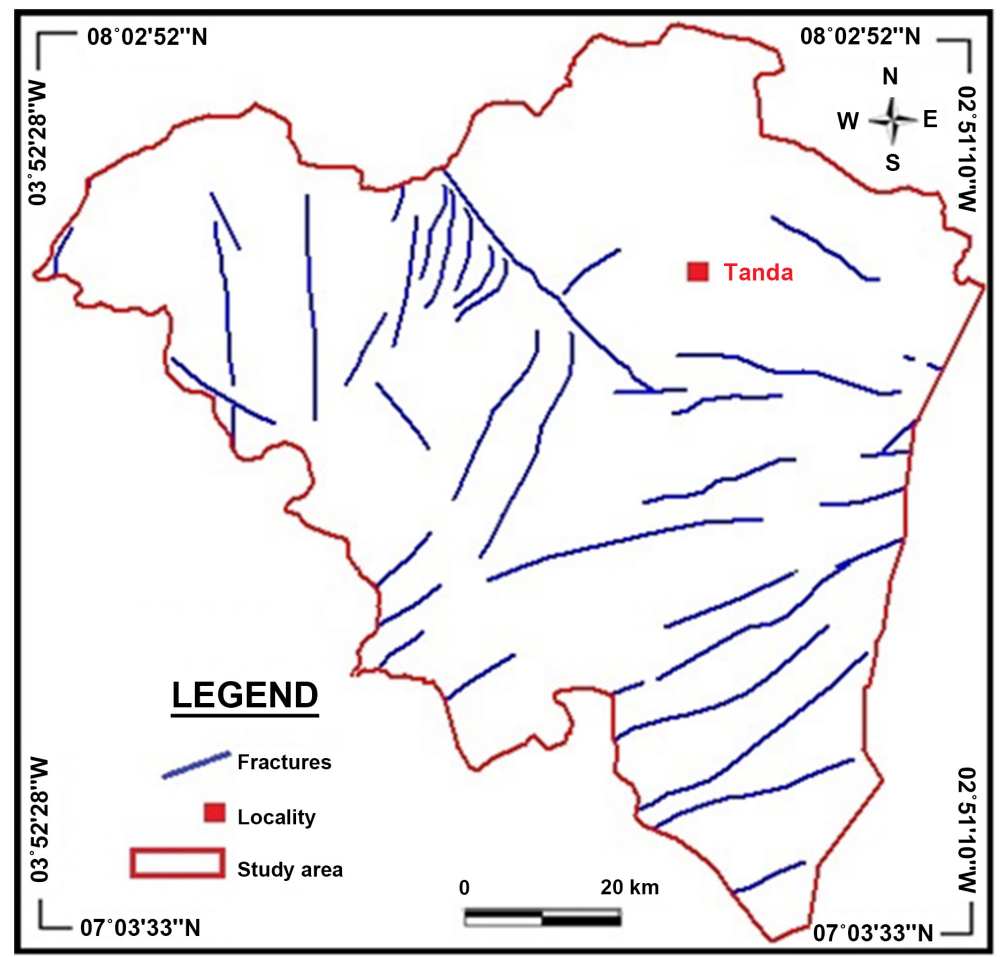

Figure 7. Fractures map from geological map of TANDA region. 


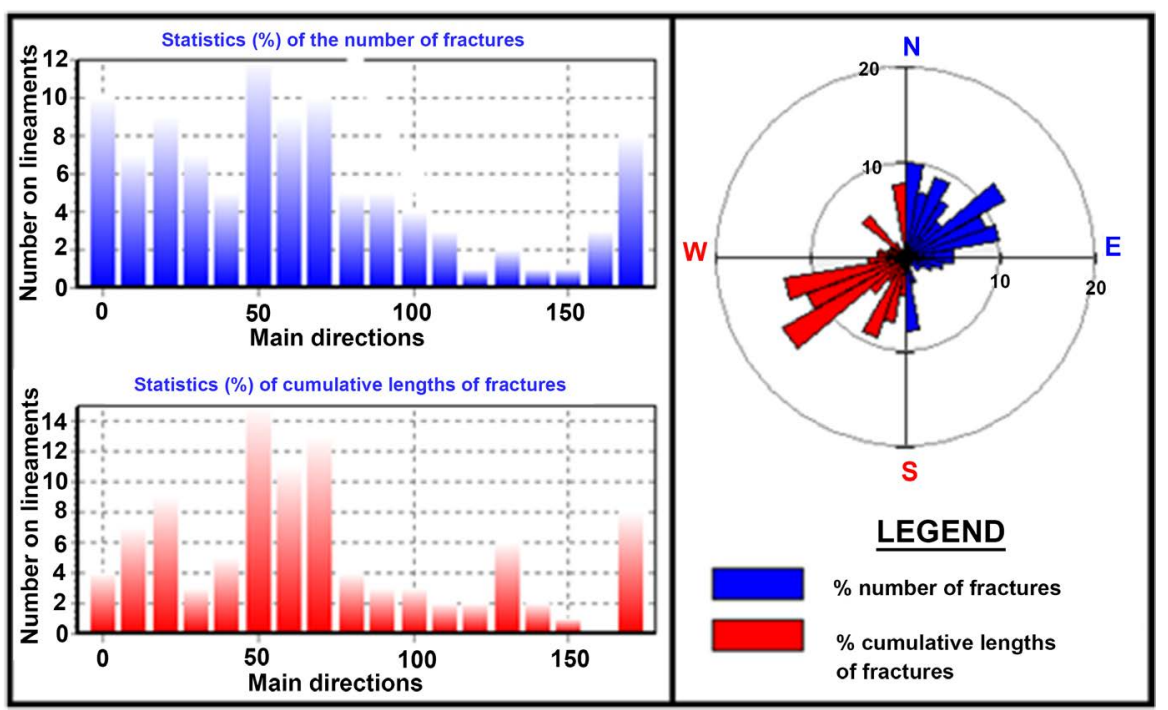

Figure 8. Graphical representation of statistical parameters of fractures.

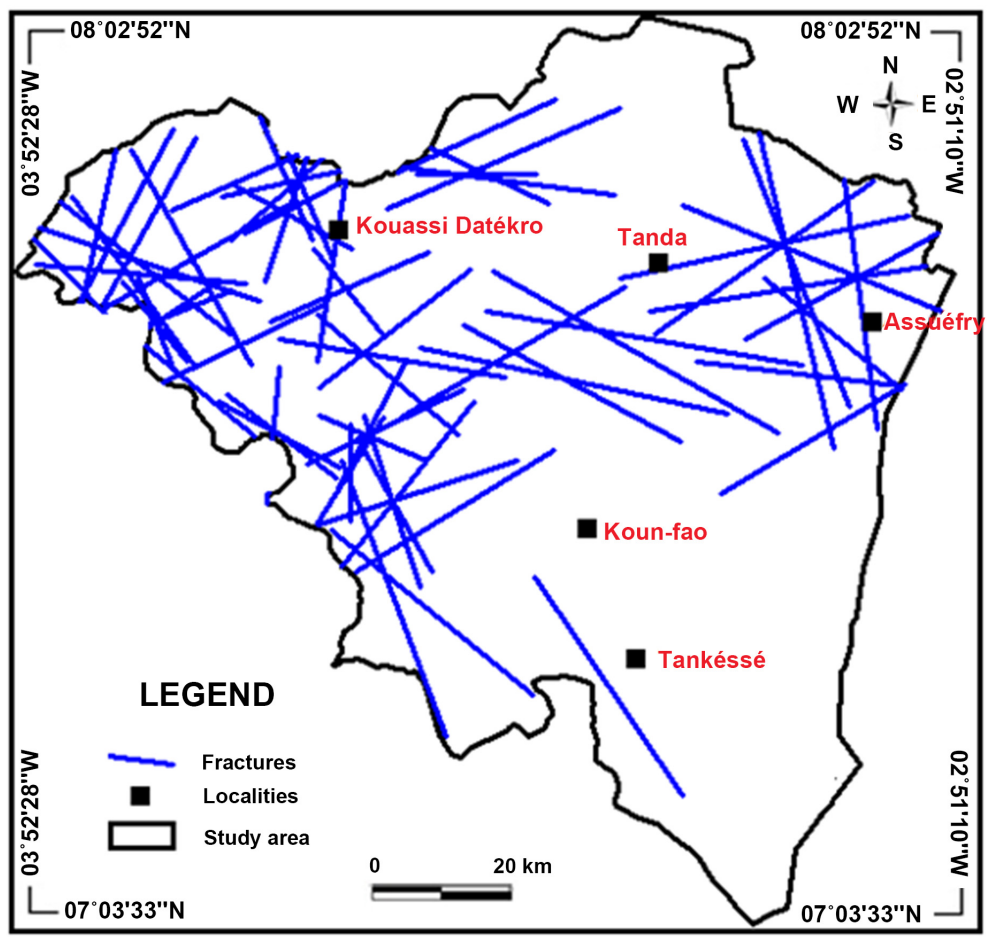

Figure 9. Fracture map from electric trailed data of Tanda area. NB: fractures shown are not at scale.

(10\%), N0-10 (9\%), N50-60 (9\%) and N60-70 (9\%). These directions can be assimilated to those of NW-SE, NS, NE-SW and to a certain extent E-W. This validation effectively confirms N-S direction of the linear map and those of NE-SW and N-S identified on the geological map.

Statistical analysis of the fracture network highlighted the main directions. The direction N00-10 or N-S is as good on the satellite images as on the geological map. This direction was also identified by [11] in the mountainous West of 

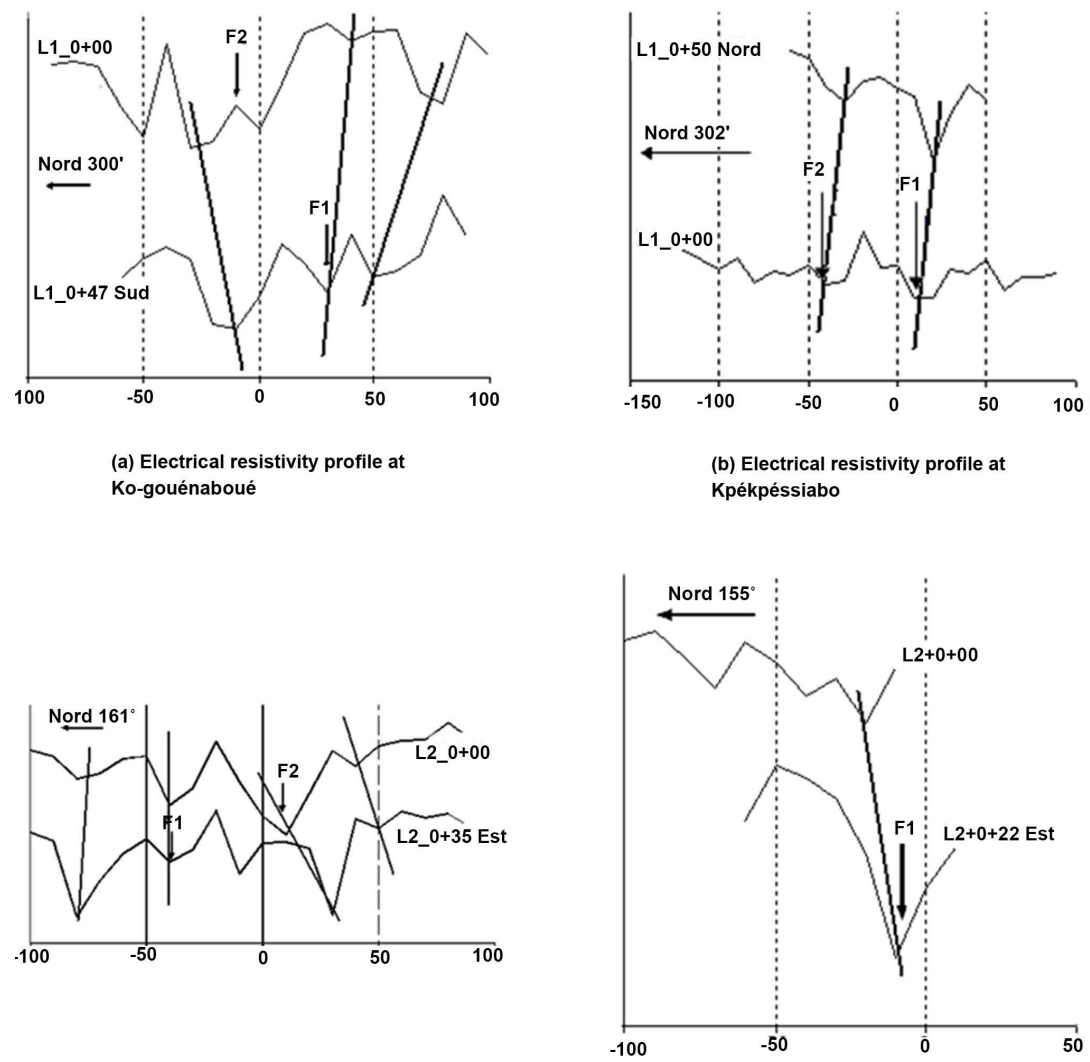

(c) Electrical resistivity profile at Nao

(d) Electrical resistivity profile at Nao
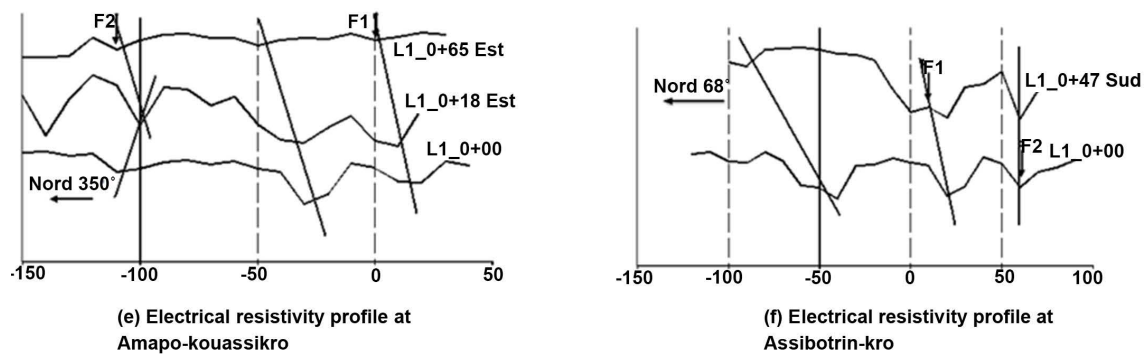

Figure 10. Example of lineament plot from electrical profiles.

Côte d'Ivoire, by [10] in the Korhogo region, by [12] in the Bondoukou region and by [13] in the region of Agboville. However, the major lineament direction N90-100 (E-W) was not observed at the geological map. This could be explained by the biases often associated with the fracturing measurement in the field [8] [14] or by a scale effect related to the types of objects considered for the determination of directional families [15]. Contrariwise, this direction E-W is clearly highlighted by the electrical profiles. This confirms the good orientation of the electrical trailings. The two directions N-S and E-W were also highlighted by [16].

The fracturing map thus obtained constitutes an important support for the implantation of boreholes in the region. The approach combining the inventory of lineaments on the satellite image, exogenous data and fieldwork leads to the 


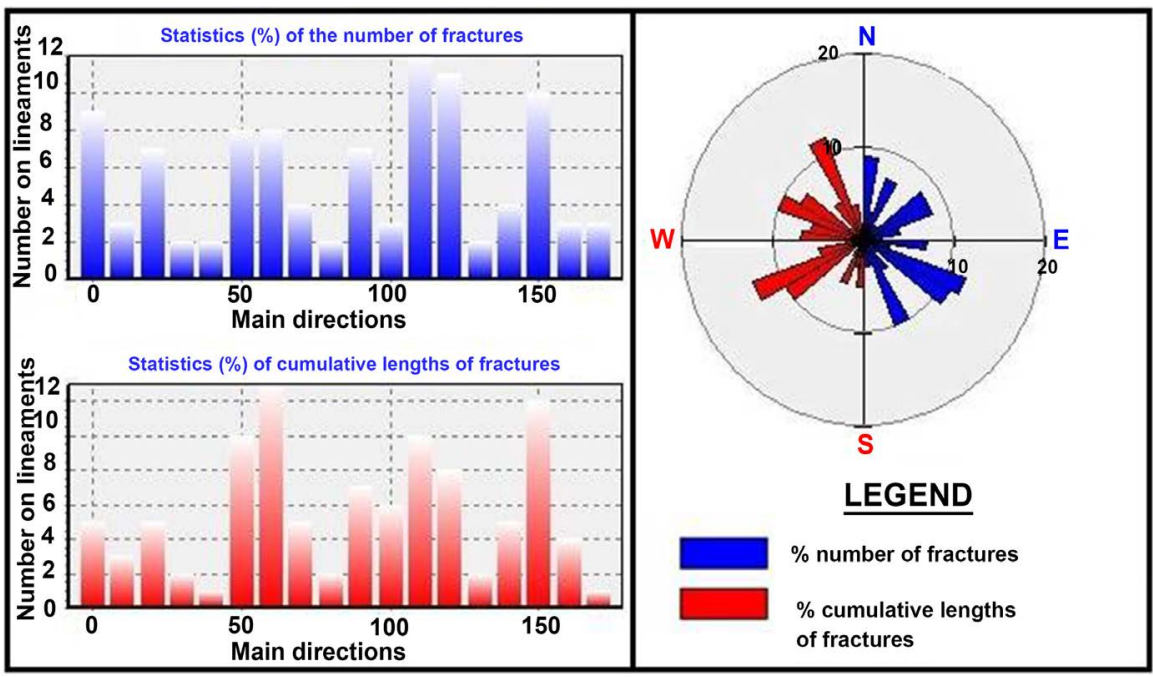

Figure 11. Directional rosettes of fractures from geophysics.

establishment of fractures classification of and the understanding of geological structures [17]. According to the same authors, this study of the lineaments makes it possible to guide the reconnaissance campaigns by defining potentially favorable zones and to select the punctual sites for the implantation of boreholes.

This geophysical prospecting has made it possible to install boreholes whose rates of flow are generally sufficient for water supply of rural populations. In order to validate the fractures and guide future hydrogeological surveys in the region, a study of structures productivity in relation with fracturing directions was conducted. This study consists of characterizing the most productive fracturing directions. Thus, we associated with each drilling fractures direction that it is supposed to capture. This approach was made possible by the superposition of drilling and fracturing maps.

Drilling flows distribution according to the fracturing directions is summarized in Table 1.

The most productive fracture directions in order of importance are NE-SW, NW-SE and E-W and to some extent N-S. They represent respectively $24.24 \%$, $21.21 \%, 15.15 \%$ and $6.06 \%$. These most productive directions correspond to those of the major fracturing families of Tanda region. Consequently, these rates of flow are related to the main fracturing directions of the region. However, an exceptional flow of $30 \mathrm{~m}^{3} \cdot \mathrm{h}^{-1}$ obtained in the village of Yaokro was recorded on an N-S fracture.

The main productive directions of the study area were also identified in Korhogo region. The NE-SW and N-S directions correspond to eburnean directions and the NW-SE direction is associated with the liberian one. In addition to the Landsat ETM+ data, these main directions have been highlighted using a GIS [18].

In Figure 12, the drillings implanted on the fracturing map were positioned. 
Table 1. Flow distribution according to fracture directions.

\begin{tabular}{ccccc}
\hline Directions & NE-SW $\left(30^{\circ}-60^{\circ}\right)$ & NW-SE $\left(120^{\circ}-150^{\circ}\right)$ & E-W $\left(80^{\circ}-110^{\circ}\right)$ & N-S $\left(0^{\circ}\right)$ \\
\hline Pourcentage & 24.24 & 21.21 & 15.15 & 6.06 \\
\hline
\end{tabular}

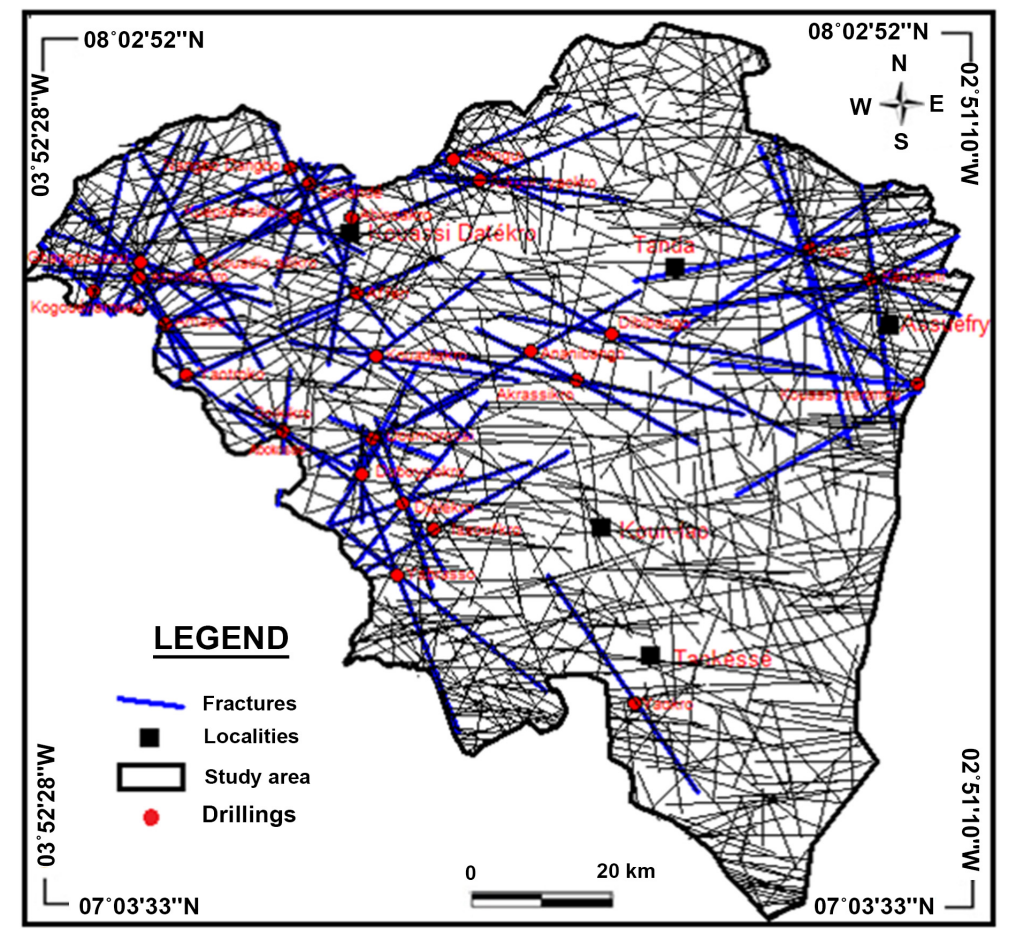

Figure 12. Superimposition map of boreholes on lineament and fracturing maps NB: Fractures shown are not at scale.

\subsection{Interpretation of Electric Sounding Curves}

Different sounding curves (Figure 13) were constructed from the electrical sounding data.

Their interpretation highlights the succession of geological formations (aquifers or not). Thus, we identify three geoelectric levels (Figure 14) that are from top to bottom:

- level I: it includes two to three superficial layers of relatively high and variable resistivities (from $100 \Omega \cdot \mathrm{m}$ to $3538 \Omega \cdot \mathrm{m}$ ) and relatively low thicknesses (2 - $49 \mathrm{~m}$ ). This very heterogeneous surface cover is composed of topsoil ( $\mathrm{h}=$ $0.35-4.86 \mathrm{~m})$, lateritic cuirass and lateritic clays $(\mathrm{h}=1.7-44 \mathrm{~m})$. The arable soil is very often absent on the electrical sounding curves,

- level II: it corresponds to a heterogeneous formation consisting of an assembly of sand and/or clay sandstone. Its resistivity is variable (from $13 \Omega \cdot \mathrm{m}$ to 180 or even $240 \Omega \cdot \mathrm{m}$ ), as well as its thickness (4.8 to $61 \mathrm{~m}$ ). However, this thickness reached exceptionally $91 \mathrm{~m}$ at Kékéréni (SE9).

- level III: it constitutes the relatively resistant substratum corresponding either to the granites or to the sandstones (to Kékéréni and Sénandé), or to the schists (to Kokoyakro). The resistivity of this level increases sharply (170 $2100 \Omega \cdot \mathrm{m})$. 


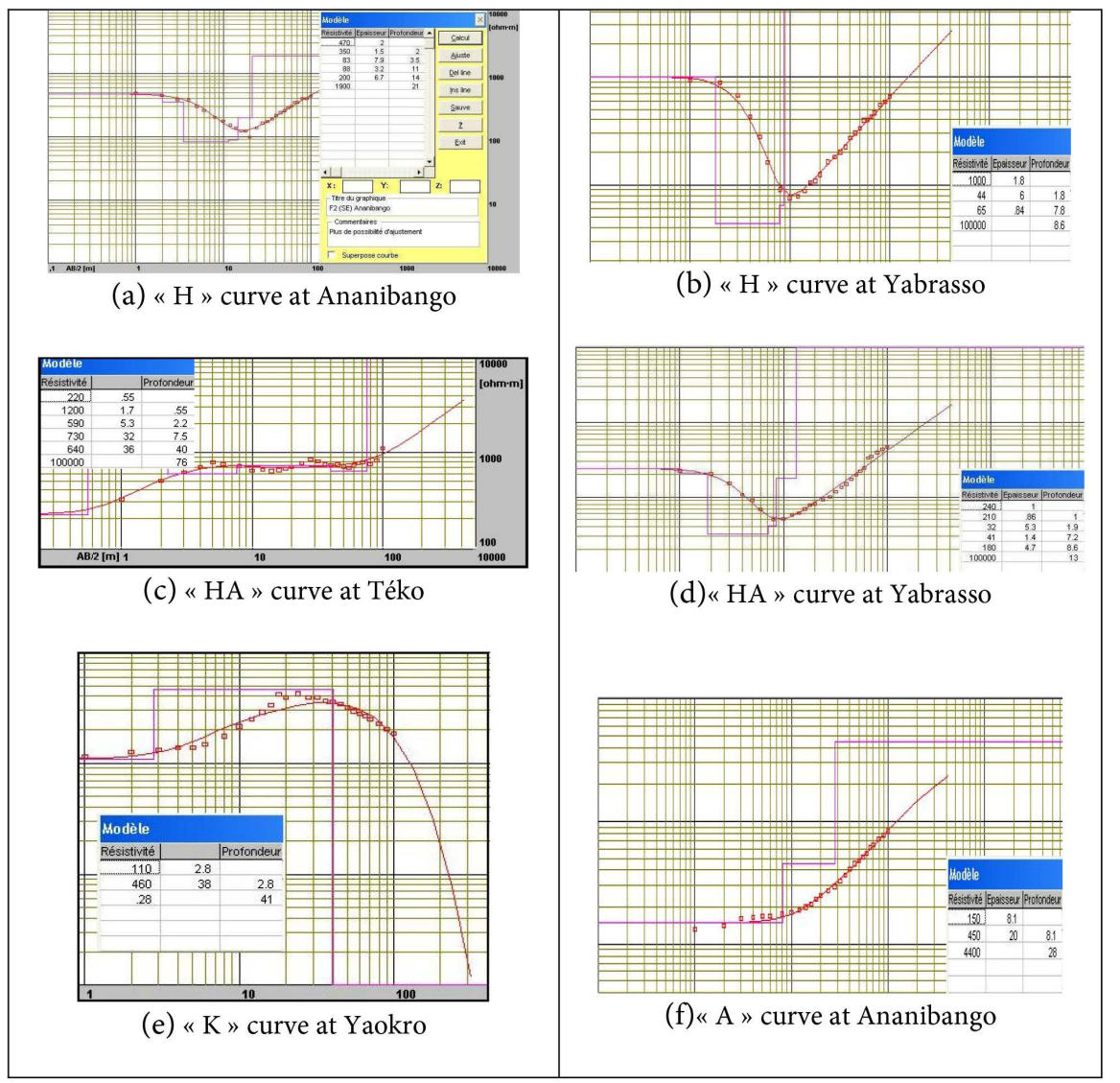

Figure 13. Examples of electrical sounding curves.

This approach and its results fit well with those of our study. Indeed, the interpretation of the sounding curves revealed the fissured zone through the vertical succession of the geological formations of the region. This potential aquifer zone corresponds to conductive anomalies found on the electrical profiles. However, this zone does not clearly delimit in geoelectric profile. Indeed, this zone is masked by clay-sandy alterites or merged with the base. This is explained by its small thickness or by the low contrast of resistivities between this layer and those surrounding. Very often, the passage of alterites to healthy rock is carried out with a progressive resistivity which does not define a precise limit between these two formations. This limit, determined by electrical soundings, is a function of the resistivity contrast between the two neighboring geological formations. If this contrast is great, the alterites and fissured rock are clearly distinguishable; cracked rock and unaltered rock then constitute a single resistant set [19]. On the other hand, if the contrast is weak, the clayey weathering and cracked rock merge; there is therefore overestimation of alterites thicknesses [1].

\subsection{Study of the Drilling Flows}

The drilling flows vary between 0.5 (Akrassikro) and $30 \mathrm{~m}^{3} \cdot \mathrm{h}^{-1}$ (Yaokro) with an average of $4.22 \mathrm{~m}^{3} \cdot \mathrm{h}^{-1}$. To appreciate the distribution of these drilling flows, a classification based on that of the Inter-African Committee of Hydraulic Studies 


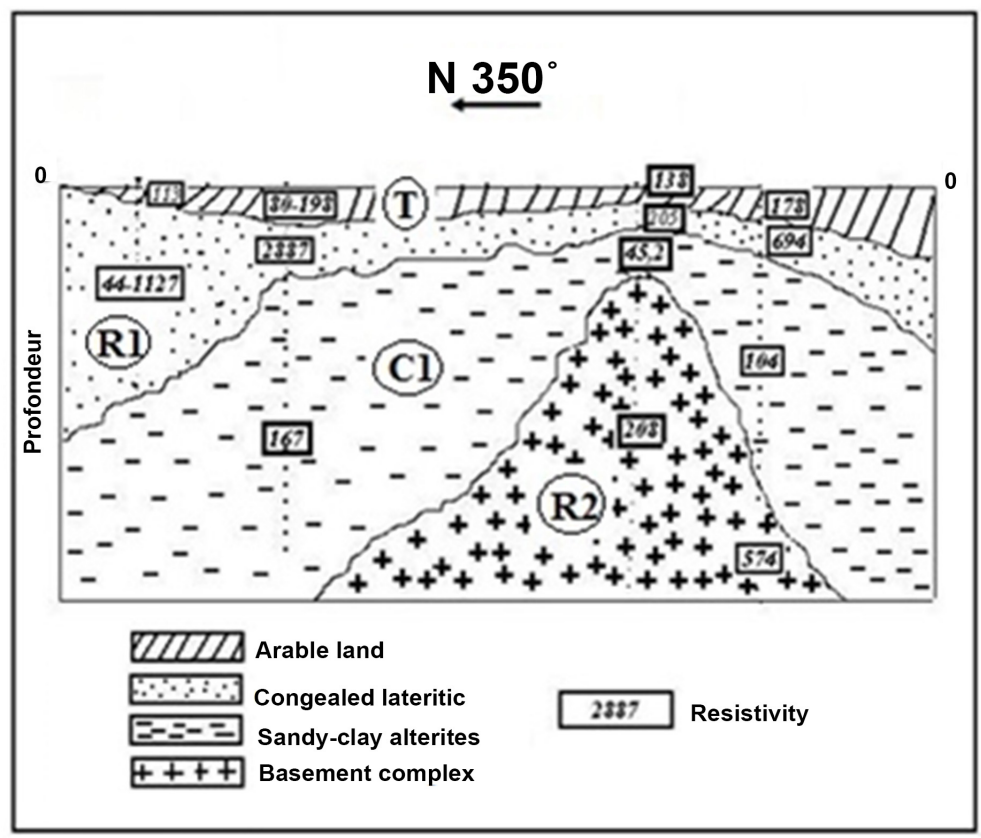

Figure 14. Geoelectric profile in the village of Kékéréni.

(C.I.E.H.) has been proposed. Thus, approximately $76.6 \%$ of the structures produce a flow rate $\mathrm{Q}>1 \mathrm{~m}^{3} \cdot \mathrm{h}^{-1}$ (of which $50 \%$ of flow rates $\mathrm{Q}>2.5 \mathrm{~m}^{3} \cdot \mathrm{h}^{-1}$ ), acceptable flow rates for a drinking water supply for rural populations (Table 2). However, for the water supply of large villages, higher flows $\left(\geq 5 \mathrm{~m}^{3} \cdot \mathrm{h}^{-1}\right)$ are required.

Good water yields obtained from drillings implanted at the level of anomalies indicate the presence of the aquifer zone.

\section{Conclusions}

Fractures are accumulations and underground flows seat and are sought during hydrogeological surveys. In Tanda region, a multidisciplinary approach has been used to locate them. Indeed, these geological structures were extracted from the satellite images. Their main directions are N00-10 (N-S), N90-100 (E-W), N70-80 and N100-110. Then, electrical resistivity method identified fractures in the field. Electrical profiles confirmed the fracture directions (NW-SE N-S and NE-SW) while electric sounding curves interpretation led to the determination of their depth. This technique has also characterized the geological formations that overhang the fractured zones. It is first the surface covering which is made up of cuirass and lateritic clays and possibly topsoil and whose electrical resistivity is relatively strong (from $100 \Omega \cdot \mathrm{m}$ to $3538 \Omega \cdot \mathrm{m}$ ). Then, the second level corresponds to an assembly of sands and/or clay sandstone whose resistivity varies between $13 \Omega \cdot \mathrm{m}$ to 180 or $240 \Omega \cdot \mathrm{m}$. Finally, below, one meets the relatively resistant substratum $(170-2100 \Omega \cdot \mathrm{m})$ corresponding either to the granites or to sandstones (to Kékéréni and Sénandé), or to schists (to Kokoyakro). The coupling of these two geophysical techniques has contributed to drill holes which provided water yields of $4.22 \mathrm{~m}^{3} \cdot \mathrm{h}^{-1}$. 
Table 2. Classification of flows (C.I.E.H.).

\begin{tabular}{cccc}
\hline Sequence & Flow classes $\mathrm{Q}\left(\mathrm{m}^{3} / \mathrm{h}\right)$ & Number of drillings & \% per flow class \\
\hline 1 & $0-1$ & 7 & 23.33 \\
2 & $1-2.5$ & 8 & 26.66 \\
3 & $2.5-5$ & 9 & 30 \\
4 & $\mathrm{Q}>5$ & 6 & 20 \\
& Total & 30 & 100 \\
\hline
\end{tabular}

Also, this study of fracturing directions indicates that the most productive are those of NE-SW, NW-SE, N-S and to some extent E-W. So, the most productive fractures are similar to the major fracturing directions of Tanda region.

Ultimately, this study reveals the complementarity and the operability of these methods and techniques in the localization of aquifers in the basement area. It also allows better implementation of future drilling in the region.

\section{Acknowledgements}

The authors would like to gratefully thank the anonymous reviewers for their critical comments and suggestions which helped in improving this manuscript. They also thank and testify their recognition to the responsible of the Department of Ministry of the Economic Infrastructures of the Tanda area (Côte d'Ivoire) for the data used in this study.

\section{Conflicts of Interest}

Authors declare that no competing interests exist.

\section{References}

[1] Coulibaly, A. (2014) Contribution de la méthode de résistivité électrique (Traînés et Sondages électriques) à la localisation d'aquifères en zone de socle cristallin et cristallophyllien: Cas de la région de Tanda, (Nord-est de la Côte d'Ivoire). Thèse unique de doctorat, Université Félix Houphouët-Boigny de Cocody.

[2] AFRIMAG (2014) Entretien du Directeur Générale de l'Office National Eau Potable de Côte d'Ivoire. Magasine $\mathrm{N}^{\circ} 75$-septembre 2014, Focus.

[3] I.N.S. (2014) Institut National de la Statistique, Secrétariat Technique Permanent du Comité Technique du RGPH (Recensement Général de la Population et de l'Habitat): Résultats globaux.

[4] Siméon, Y., Délor, C., Zeadé, Z., Koné, Y., Yao, B., Vidal, M., Diaby, I., Konan, G., Djé, B.I., N'da, D., Dommanget, A., Cautru, J.P., Guerrot, C. and Chiron, J.-C. (1995) Notice explicative de la carte géologique de la Côte d'Ivoire à 1/200 000, feuille Agnibilékro. Mémoire de la Direction des Mines et de la Géologie de la Côte d'Ivoire, No. 8.

[5] Zeadé, Z., Delor, C., Siméon, Y., Yao, B.D., Vidal, M., Sonnendrucker, P., Diaby, I. and Cautru, J.P. (1995) Notice explicative de la Carte Géologique de la Côte d'Ivoire à 1/200000, Feuille Bondoukou. Mémoire de la Direction des Mines et de la Géologie de la Côte d'Ivoire, No. 10.

[6] Touré, S. (2007) Pétrologie et géochronologie du massif granitoïde de Bondoukou. 
Nord Est de la Côte d'Ivoire. Évolution magmatique et contexte géodynamique au Protérozoïque inférieur. Relations avec le volcano détritique du Zanzan, Koun, Tanda, attribué au Tarkwaïen du Ghana. Implications paléogéographiques. Thèse de Doctorat ès Sciences Naturelles, Université d'Abobo-Adjamé.

[7] Faillat, J.P. (1986) Hétérogénéité et effet d'échelle dans les aquifères fissurés. Approche par pompage d'essai sur station expérimentale (Afrique de l'Ouest). $\mathrm{Hy}$ drogéologie, 1, 65-76.

[8] Lasm, T. (2000) Hydrogéologie des réservoirs de socle: Analyses statistique et géostatistique de la fracturation et des propriétés hydrodynamiques. Application à la région des montagnes de Côte d'Ivoire (domaine archéen). Thèse de doctorat unique, Faculté des sciences Fondamentales et Appliquées, Université de Poitiers, Poitiers.

[9] Maréchal, J.C., Dewandel, B. and Subrahmanyam, K. (2004) Use of Hydraulic Tests at Different Scales to Characterize Fracture Network Properties in the Weathered Fractured Layer of a Hard Rock Aquifer. Water Resources Research, 40, 1150801-1150817. https://doi.org/10.1029/2004WR003137

[10] Jourda, J.P.R. (2005) Méthodologie d'application des techniques de télédétection et des systèmes d'information géographique à l'étude des aquifères fissurés d'Afrique de l'Ouest. Concept de l'hydrotechnique spatiale: Cas des zones tests de la cote d'ivoire. Thèse de Doctorat d'État ès Sciences Naturelles, Université de Cocody, Abidjan.

[11] Kouamé, K.F. (1999) Hydrogéologie des aquifères discontinus de la région semi-montagneuse de MAN-DANANE (Ouest de la Côte d'Ivoire). Apport des données des images satellitales et des méthodes statistiques et fractales à l'élaboration d'un système d'information hydrogéologique à référence spatiale. Thèse de Doctorat de $3^{\mathrm{e}}$ cycle, Université de Cocody, Abidjan.

[12] Youan, Ta.M. (2008) Contribution de la télédétection et des systèmes d'informations géographiques à la prospection hydrogéologique du socle précambrien d'Afrique de l'Ouest: Cas de la région de Bondoukou (nord-est de la Côte d'Ivoire). Thèse unique de doctorat, Université de Cocody, Abidjan.

[13] Ahoussi, K.E. (2008) Évaluation quantitative et qualitative des ressources en eau dans le Sud de la Côte d'Ivoire. Application de l'hydrochimie et des isotopes de l'environnement à l'étude des aquifères continus et discontinus de la région d'Abidjan-Agboville. Thèse unique de doctorat, Université de Cocody, Abidjan.

[14] Koita, M. (2010) Caractérisation et modélisation du fonctionnement hydrodynamique d'un aquifère fracturé en zone de socle. Région de Dimbokro-Bongouanou (Centre Est de la Côte d'Ivoire). Thèse unique de doctorat, Université de Montpellier II, Montpellier.

[15] Mangoua, J. (2013) Evaluation des potentialités et de la vulnérabilité des ressources en eau souterraine des aquifères fissures du bassin versant de la Baya (Est de la Côte d'Ivoire).Thèse de doctorat unique, Université Nangui Abrogoua, Abidjan.

[16] Abdou Babaye, M.S. (2012) Evaluation des ressources en eau souterraine dans le bassin de Dargol (Liptako-Niger). Thèse de doctorat, Université de Liège, Liège.

[17] Bérard, P., Castaing, C. and Scanvic, J.Y. (1990) Alimentation en eau de la Mine d'or d'Hassai (Soudan): Impact de l'étude de télédétection. Hydrogéologie, 2, 101-111.

[18] Jourda, J.P.R., Saley, M.B., Djagoua, E.V., Kouamé, K.J., Biémi, J. and Razack, M. (2006) Utilisation des données ETM+ de Landsat et d'un SIG pour l'évaluation du potentiel en eau souterraine dans le milieu fissuré précambrien de la région de 
Korhogo (Nord de la Côte d'Ivoire): Approche par analyse multicritère et test de validation. Télédétection, 5, 339-357.

[19] COMTEC (1968) Enquêtes sur les ressources minières et les ressources en eaux souterraines en Haute-volta. U.N Compag. Tech. du Progettazione, Rome. 